\title{
ANALISIS HUBUNGAN PERANAN BUDAYA PERUSAHAAN TERHADAP PENERAPAN GOOD CORPORATE GOVERNANCE PADA PT ANEKA TAMBANG TBK
}

\author{
Rindang Widuri ${ }^{1}$; Asteria Paramita ${ }^{2}$
}

\begin{abstract}
This article examines the relationship between company cultures with Good Corporate Governance (GCG). It used survey method and correlational technique by distributing questioner with two instruments, namely company cultures and GCG. The respondents were employees of PT. Aneka Tambang Tbk consisting of 100 persons for which 87 persons were selected determined using Sugiyono books formula. The sample were determined using simple random sampling. The study used simple linear regression and simple cr relational technique. The results show that there is a strong correlation between company culture and GCG. It means that the stronger of company culture implementation the more intention to implement GCG.
\end{abstract}

Keywords: company culture, good corporate governance ABSTRAK
Artikel ini bertujuan mengetahui hubungan antara peran budaya perusahaan
dengan good corporate governance(GCG). Metode penelitian yang digunakan adalah
metode survei dan teknik colerasional dengan cara menyebarkan kuesioner dengan dua
jenis instrumen, yaitu instrumen budaya perusahaan dan GCG. Responden adalah
karyawan tetap PT Aneka Tambang Tbk yang berjumlah 100 orang dan dipilih 87 orang
yang ditentukan dari rumus buku Sugiyono dan dipilih dengan teknik probability
sampling pada simple random sampling. Analisis data menggunakan regresi liniear
sederhana dan teknik korelasional sederhana. Hasil penelitian menunjukkan adanya
korelasi kuat antara budaya perusahaan dengan good corporate governance, artinya
semakin kuat penerapan budaya perusahaan maka akan semakin tinggi penerapan GCG.

Kata kunci: budaya perusahaan, good corporate governance

1, 2 Jurusan Akuntansi, Fakultas Ekonomi, Universitas Bina Nusantara, Jl. K.H. Syahdan No. 9, Palmerah, Jakarta Barat 11480, rindangw@binus.edu 


\section{PENDAHULUAN}

Setelah mengalami krisis ekonomi beberapa tahun lalu, kondisi perekonomian Indonesia hingga saat ini belum menunjukkan kemajuan pesat. Salah satu faktor yang menyebabkan lambatnya proses pemulihan kondisi perekonomian adalah belum diterapkannya corporate governance yang baik. Oleh karena itu, corporate governance yang baik menjadi bagian penting dalam proses pembaharuan ekonomi untuk mengatasi krisis ekonomi. Hal itu menjadi motivasi para pelaku usaha untuk dapat menerapkan GCG pada perusahaan yang dikelola.

Dalam perkembangannya, GCG semakin penting bagi perusahaan, yakni sebagai alat control manajemen dalam meningkatkan kinerja perusahaan dan upaya menciptakan perusahaan yang sehat. GCG dalam penerapannya akan mengatur hubungan antara manajemen perusahaan, komisaris, direksi, pemegang saham, dan kelompok kepentingan (stakeholders) yang lain. Selanjutnya akan dimanifestasikan dalam bentuk kerangka kerja yang diperlukan untuk menentukan tujuan perusahaan dan cara pencapaian tujuan serta pemantauan kinerja yang dihasilkan. Sebagian besar perusahaan multinasional tersebut memiliki karakteristik pemisahan fungsi kepemilikan perusahaan dan manajemen pengelolaan perusahaan.

Perusahaan multinasional, seperti PT Aneka Tambang, Tbk sebagai salah satu perusahaan perseroan terbuka (go public), baik di Indonesia maupun di Australia, yang telah mengimplementasikan konsep GCG untuk mewujudkan visi 2010, yaitu perusahaan pertambangan yang berstandar internasional. Dengan pengimplementasian GCG ini, PT Aneka Tambang, Tbk. telah meraih dua kali penghargaan berupa BUMN Award dalam Implementasi Good Corporate Governance dan Annual Report Award pada tahun 2002 dan 2003. Sebagai perusahaan yang telah mengimplementasikan GCG, PT Aneka Tambang, Tbk. memerlukan pedoman konsep manajemen yang dapat mengatur sikap dan tingkah laku karyawan. Diantaranya adalah budaya perusahaan untuk merumuskan karakteristik tertentu dalam perusahaan dan penerapan GCG untuk menjadi landasan yang kokoh dalam menjalankan manajemen perusahaan.

Dari penjelasan tersebut, artikel membahas analisis peranan budaya perusahaan terhadap penerapan GCG pada PT Aneka Tambang, Tbk. Penelitian dilakukan dengan tujuan untuk mengetahui besarnya peranan budaya perusahaan terhadap penerapan GCG pada PT Aneka Tambang, Tbk. Hasil penelitian diharapkan dapat memberikan manfaat bagi PT Aneka Tambang, Tbk., khususnya dalam hal pengembangan peran budaya perusahaan untuk meningkatkan GCG di perusahaan. Selain itu, penulis diharapkan penelitian ini juga bermanfaat bagi semua pihak yang terlibat, bagi masyarakat dan terlebih bagi pengembangan ilmu pengetahuan. 
Berdasarkan uraian tersebut, dapat dilakukan identifikasi masalah, yaitu seberapa besar peranan budaya perusahaan terhadap pelaksanaan GCG pada PT Aneka Tambang, Tbk. dan bagaimana manfaat yang didapat PT Aneka Tambang, Tbk dengan pelaksanaan GCG.

Penelitian bertujuan untuk menguji hal yang menjadi budaya perusahaan di PT Aneka Tambang, Tbk., menganalisis besarnya peranan budaya perusahaan terhadap pelaksanaan GCG pada PT Aneka Tambang, Tbk., dan mengetahui manfaat yang didapat PT Aneka Tambang, Tbk. dengan pelaksanaan GCG. Manfaat yang diharapkan adalah memberikan acuan yang dapat digunakan sebagai pedoman untuk suatu perusahaan mengenai perlunya memasukkan aspek yang terkait dengan GCG dalam pembentukkan budaya perusahaan, memberikan acuan untuk mengetahui tingkat kemampuan budaya perusahaan dalam mendorong pelaksanaan GCG di PT Aneka Tambang, Tbk., dan memberikan gambaran mengenai penerapan budaya perusahaan terhadap pelaksanaan GCG pada perusahaan, baik perusahaan swasta, BUMN, maupun dalam organisasi pemerintahan.

\section{TINJAUAN PUSTAKA}

Menurut Nawawi (2003:283) yang dikutip dari Cushway B. dan Lodge D., hubungan budaya dengan budaya organisasi bahwa "budaya organisasi adalah suatu kepercayaan dan nilai yang menjadi falsafah utama yang dipegang teguh oleh anggota organisasi dalam menjalankan atau mengoperasionalkan kegiatan organisasi”. Nawawi (2003:283) yang dikutip dari Schemerhom, Hurn, dan Osborn, mengatakan "budaya organisasi adalah suatu sistem penyebaran keyakinan dan nilai yang dikembangkan dalam suatu organisasi sebagai pedoman perilaku anggotanya".

Moorhead dan Ricky (1999:513) memberikan definisi budaya organisasi sebagai, "The set of values that helps the organization's employees understand which actions are considered acceptable and which unacceptable". Budaya organisasi merupakan kumpulan nilai yang membantu anggota organisasi memahami tindakan yang dapat diterima dan mana yang tidak dapat diterima dalam organisasi. Nilai tersebut biasanya dikomunikasikan melalui cerita atau simbol lain yang mempunyai arti tertentu bagi organisasi.

Triguno (2000:184) menyatakan "budaya organisasi adalah campuran nilai kepercayaan dan norma yang ditetapkan sebagai pola perilaku dalam suatu organisasi”. Dari berbagai definisi budaya organisasi yang telah dikemukakan, dapat ditarik simpulan bahwa budaya perusahaan adalah sistem nilai yang diyakini oleh semua anggota perusahaan dan yang dipelajari, diterapkan, serta dikembangkan secara berkesinambungan, berfungsi sebagai sistem perekat, dan dapat dijadikan acuan berperilaku dalam perusahaan untuk mencapai tujuan perusahaan yang telah ditetapkan. 


\section{Karakteristik Budaya Organisasi}

Menurut Stephen P. Robbins yang dikutip oleh Arasy (2002:139), suatu budaya organisasi akan berdampak pada kinerja diawali dari input organisasi yang meliputi inovasi dan pengembangan risiko, perhatian ke rincian, orientasi hasil, orientasi orang, orientasi tim, keagresifan, dan kemantapan yang kemudian dipersepsikan sebagai budaya organisasi yang akan menjadi sebuah kekuatan yang tinggi atau rendah yang berdampak pada tingkat kinerja dan kepuasan karyawan. Kepuasan kerja berupaya mengukur respons efektif terhadap lingkungan kerja. Kepuasan kerja berhubungan dengan bagaimana perasaan pegawai, seperti praktik imbalan yang diberikan oleh organisasi.

\section{Pentingnya Budaya Organisasi}

Menurut Lowney (2005:341), hasil riset yang diselenggarakan oleh para konsultan manajemen McKinsey \& Co, untuk melancarkan strategi membantu perusahaan menarik dan mempertahankan para karyawan berbakat yang langka, McKinsey bertanya kepada para eksekutif puncak, apa yang telah memotivasi para karyawan mereka yang paling berbakat. Berikut ini adalah ringkasan di antara 200 eksekutif puncak mengenai peringkat faktor yang mutlak essensial untuk memotivasi karyawan berbakat.

Tabel 1 Peringkat Faktor Untuk Memotivasi Karyawan

\begin{tabular}{|l|l|}
\hline Nilai-nilai Budaya & $58 \%$ \\
\hline Kebebasan Otonomi & $56 \%$ \\
\hline Tugas Mengandung Tantangan & $51 \%$ \\
\hline Pengelolaan yang baik & $50 \%$ \\
\hline Kompensasi yang tinggi & $23 \%$ \\
\hline Misi yang mengilhami & $16 \%$ \\
\hline
\end{tabular}

Sumber: Lowney (2005:341)

Hasil riset menunjukkan bahwa nilai dalam budaya organisasi sangat mempengaruhi motivasi para anggota dalam bekerja. Supaya seseorang dapat menjalankan fungsinya secara efektif dalam suatu organisasi, seseorang perlu tahu bagaimana mengerjakan atau harus mengerjakan sesuatu, termasuk bagaimana berperilaku sebagai anggota organisasi, khususnya dalam lingkungan organisasinya. Dengan adanya budaya organisasi yang jelas maka seseorang dapat mengerti aturan main yang harus dijalankan, baik dalam mengerjakan tugasnya, maupun dalam berinteraksi dengan sesama anggota dalam organisasi. Ketidakraguan dalam menjalani hal ini akan membawa peneguhan bagi seseorang, yang membuatnya mengerti apa yang harus dan tidak boleh dilakukan. Budaya akan meningkatkan komitmen organisasi dan 
meningkatkan konsistensi dari perilaku karyawan. Dari sudut pandang karyawan, budaya memberitahu mereka bagaimana segala sesuatu dilakukan dan apa yang penting (Gea, 2005:326).

\section{Good Corporate Governance (GCG)}

Menurut YPPMI (2002:21), GCG adalah seperangkat peraturan yang mengatur hubungan antara pemegang saham, pengelola perusahaan, pihak kreditor, pemerintah, karyawan, serta pemegang kepentingan intern dan ekstern lainnya yang berkaitan dengan hak dan kewajiban mereka, atau dengan kata lain suatu sistem yang mengatur dan mengendalikan perusahaan.

Menurut Aldrige (2005:2), the Organization for Economic Cooperation and Development (OECD) mendefinisikan corporate governance sebagai berikut: "Corporate governance is the system by wich business corporations are directed and controlled. The corporate governance structure specifies the distribution rights and responsibilities among different participants in the corporation, such as the board, the mangers, shareholders and other stakeholders, and spell out rules and procedure for making decisions on corporate affairs. By doing this, it also provides the structure through which the company objectives are set, and the means of attaining those objectives and monitoring performance".

Sesuai dengan definisi tersebut, menurut OECD Corporate Governance adalah sistem yang dipergunakan untuk mengarahkan dan mengendalikan kegiatan bisnis perusahaan. Corporate governance mengatur pembagian tugas, hak, dan kewajiban mereka yang berkepentingan terhadap kehidupan perusahaan, termasuk pemegang saham, Dewan Pengurus, para manajer, dan semua anggota the stakeholders non-pemegang saham.

Dapat disimpulkan bahwa GCG adalah seperangkat peraturan yang mengatur hubungan antara pemegang saham, pengelola perusahaan, pihak kreditor, pemerintah, karyawan, serta pemegang kepentingan intern dan ekstern lainnya yang berkaitan dengan hak dan kewajiban mereka, atau dengan kata lain suatu sistem yang mengatur dan mengendalikan perusahaan untuk mencapai kinerja bisnis yang optimal.

Menurut Moeljono (2005:19), ada lima karakteristik GCG. Pertama, Transparansi, yaitu keterbukaan dalam melaksanakan proses pengambilan keputusan dan keterbukaan dalam mengungkapkan informasi material dan relevan mengenai perusahaan. Kedua, Kemandirian, yaitu keadaan tempat perusahaan dikelola secara profesional, tanpa benturan kepentingan dan pengaruh atau tekanan pihak mana pun yang tidak sesuai dengan peraturan perundang-undangan dan prinsip korporasi yang sehat. Ketiga, Akuntabilitas, yaitu kejelasan fungsi, pelaksanaan, dan pertanggungjawaban organ sehingga pengelolaan perusahaan terlaksana secara efektif. Keempat, Pertanggungjawaban, yaitu kesesuaian dalam pengelolaan perusahaan terhadap peraturan 
perundang-undangan dan prinsip korporasi yang sehat. Kelima, Kewajaran, yaitu kesesuaian dalam pengelolaan perusahaan terhadap peraturan perundang-undangan dan prinsip korporasi yang sehat.

Moeljono (2005:10) menyatakan bahwa budaya perusahaan menjadi inti empat konteks, yaitu GCG, Manajemen, Corporate Sosial Responsibilities, dan Etika Bisnis. Dikemukakan demikian karena perusahaan yang unggul dan terpuji biasanya memiliki ciri empat keunggulan tersebut. Pertama, manajemennya unggul sehingga perusahaan dapat mengkreasikan kinerja yang tinggi dan laba usaha yang optimal. Kedua, proses manajemen yang unggul dijaga oleh parktik GCG yang terdiri atas lima aspek pokok, yakni transparansi, independensi, akuntabilitas, responsibilitas, dan keadilan. Good Corporate Governace merupakan prasyarat kualitas pengelolaan korporasi yang diisyaratkan dalam persaingan global. Korporasi yang melaksanakan GCG memperoleh akseptansi yang lebih tinggi. Korporasi yang menjunjung tinggi tanggung jawab sosial akan memperoleh citra kelembagaan yang positif. Praktik itu sebenarnya digerakan oleh nilai perusahaan yang mengatakan bahwa tanggung jawab sosial bukanlah tugas, melainkan "bagian dari kehidupan korporasi". Akhirnya, korporasi yang berbisnis dengan melandaskan diri pada etika adalah korporasi yang mempunyai akseptansi yang tinggi, baik dalam lingkungan bisnis, sosial, maupun politik.

Menurut Moeljono (2005:74-75), budaya perusahaan merupakan sisi dalam atau sisi nilai dari pengelolaan korporasi, atau menjadi bagian hulu dari GCG dengan muatannya yang fokus pada basic value dari pengelolaan korporasi yang kemudian ditentukan melalui sistem. Corporate Governance memberikan perhatian pada bentuk fisik dan perilaku dari suatu perusahaan. Bentuk itu dapat dikembangkan melalui peningkatan kemampuan (skill) dan peningkatan pengetahuan (knowledge). Sementara itu, budaya perusahaan memberikan konsentrasi pada bentuk sikap. Bentuk sikap itu merupakan kepribadian individu dalam perusahaan sehingga kumpulan sikap dan interaksi kepribadian antar individu dalam perusahaan akan memunculkan karaktek perusahaan dalam dirinya. Tanpa itu, perusahaan ibarat sebuah wadah tanpa nyawa. Perusahaan yang besar, kuat, dan hidup beratus tahun sambil tetap menjadi idola dan pujaan adalah perusahaan yang kompeten yang menggerakkan seluruh bagian tubuhnya atas perintah dari dalam tubuhnya. Penggerak itu adalah budaya perusahaan sehingga dapat dikatakan bahwa budaya perusahaan merupakan inti dari GCG. 


\section{Kerangka Pemikiran Teoritis}

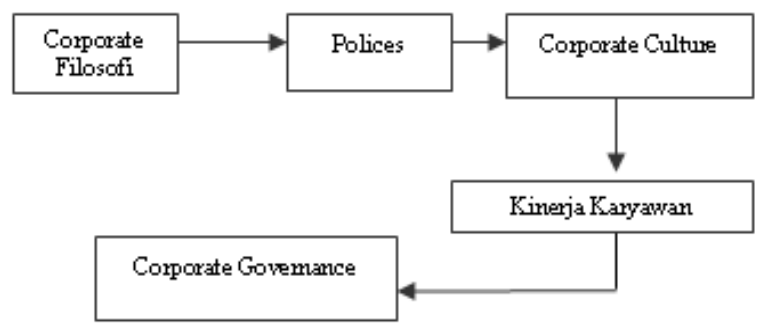

Gambar 1 Kerangka Pemikiran Teoritis

Filosofi perusahaan berasal dari pendiri perusahaan. Berbagai kebijakan yang dihasilkan perusahaan selalu didasari oleh filosofi perusahaan. Hal itu terus berkembang sehingga secara tidak kasat mata terbentuk yang dinamakan dengan budaya perusahaan. Tujuan budaya perusahaan nantinya akan menjadi tuntunan bagi peningkatan kinerja karyawan sehingga kinerja karyawan yang meningkat mampu menciptkan tata kelola perusahaan, khususnya tata kelola perusahaan yang baik. Penelitian ini bermaksud untuk meneliti mengenai budaya perusahaan merupakan salah satu alat yang dapat digunakan oleh perusahaan agar perusahaan memiliki GCG.

\section{METODE PENELITIAN}

Populasi dalam penelitian ini adalah Karyawan dan Staf pada PT Aneka Tambang, Tbk. sejumlah 2460 karyawan yang diseleksi melalui Tes CPNS maupun seleksi khusus bagi tenaga ahli yang dibutuhkan. Jumlah anggota sampel sering dinyatakan dengan ukuran sampel. Sampel dalam penelitian ini berjumlah 100 orang. Teknik pengambilan sampel dengan probability sampling, yaitu simple random sampling dan pengambilan sampel anggota populasi dilakukan secara acak tanpa memperhatikan strata yang ada dalam populasi.

Dalam penelitian ini, teknik analisis data yang digunakan adalah uji validitas, uji reliabilitas, uji normalitas menggunakan uji Liliefors, uji homegenitas dengan uji Bartlett, dan uji regresi. Instrumen penelitian yang digunakan dalam penelitian ini adalah berupa kuseioner yang terdiri dari 20 (dua puluh) pertanyaan mengenai Peranan Budaya Perusahaan sebagai variabel terikat (X) dan 20 (dua puluh) pertanyaan mengenai Penerapan GCG sebagai variabel bebas (Y). Alternatif jawaban dalam kuesioner digunakan skala Likert untuk mengukur sikap, pendapat, dan persepsi. Oleh karena itu, pilihan jawaban diberi angka atau nilai sebagai berikut: a. Sangat setuju (skor 5), b. Setuju (skor 4), c. Kurang setuju (skor 3), d. Tidak setuju (skor 2) dan e. Sangat tidak setuju (skor 1). 


\section{PEMBAHASAN}

Responden merupakan karyawan PT Aneka Tambang, Tbk. Dari keseluruhan populasi, yaitu 2460 karyawan, dipilih 100 responden sebagai sampel penelitian untuk mengisi kuesioner. Kuesioner yang terkumpul sebanyak 87 kuesioner. Berikut adalah karakteristik responden dari segi jenis kelamin, usia, pendidikan, dan lama bekerja.

Tabel 2 Karakteristik Responden

\begin{tabular}{|c|c|c|}
\hline & Jumlah & \%tase \\
\hline $\begin{array}{cl}\text { Jenis } & \text { Kelamin : } \\
\bullet & \text { Pria } \\
\bullet & \text { Wanita } \\
\end{array}$ & $\begin{array}{l}58 \\
29 \\
\end{array}$ & $\begin{array}{l}67 \% \\
33 \% \\
\end{array}$ \\
\hline 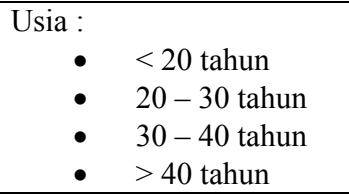 & $\begin{array}{r}0 \\
12 \\
7 \\
68\end{array}$ & $\begin{array}{r}0 \% \\
14 \% \\
8 \% \\
78 \% \\
\end{array}$ \\
\hline $\begin{array}{cl}\text { Pendidikan : } \\
\text { - } \\
\text { - } & \text { Diploma / Sederajat } \\
\text { - } & \text { S1 } \\
\text { - } & \text { S2 } \\
\end{array}$ & $\begin{array}{r}0 \\
13 \\
41 \\
33 \\
\end{array}$ & $\begin{array}{r}0 \% \\
15 \% \\
47 \% \\
38 \% \\
\end{array}$ \\
\hline $\begin{array}{c}\text { Lama Bekerja : } \\
-\quad<1 \text { tahun } \\
-\quad 1-2 \text { tahun } \\
\text { - } \quad 3-5 \text { tahun } \\
\text { - } \quad>5 \text { tahun } \\
\end{array}$ & $\begin{array}{r}10 \\
0 \\
3 \\
74 \\
\end{array}$ & $\begin{array}{r}11 \% \\
0 \% \\
3 \% \\
85 \% \\
\end{array}$ \\
\hline
\end{tabular}

Berdasarkan tabel 2, dilihat, bahwa mayoritas responden adalah berjenis kelamin laki-laki (67\%), dari sisi usia, mayoritas responden berusia berusia diatas 40 tahun (78\%), sedangkan tingkat pendidikan responden mayoritas strata 1 (47\%), dengan lama bekerja mayoritas diatas 5 tahun $(85 \%)$.

Sebelum dilakukan uji hipotesis lebih lanjut, instrumen penelitian ini telah melalui uji validitas dan uji reliabilitas (cronbach alpha). Dari uji validitas diperoleh bahwa nilai $r$ (Corrected Item-Total Correlation) untuk semua butir pertanyaan memperoleh hasil $>0,3$ yang berarti seluruh butir pertanyaan tersebut valid sedangkan berdasarkan uji reliabilitas (cronbach alpha), diperoleh hasil 0,980 yang berarti instrumen penelitian lulus uji reliabilitas.

Berdasarkan instrumen penelitian yang menggunakan skala lima diperoleh rentang teoritis antara $20-100$. Rentang skor empiris diperoleh dari skor minimal 60 dan skor maksimal 99, dengan rentang skor sebesar 39. Nilai rata - rata 84,38. Median dengan nilai 87 , modus dengan nilai 87 , varians dengan hasil 89,447 dan standar deviasi sebesar 9,458. Berikut tabel distribusi frekuensi untuk variabel budaya perusahaan (x). 
Tabel 3 Tabel Distribusi Frekuensi Penerapan Budaya Perusahaan (X)

\begin{tabular}{|c|c|c|c|c|c|c|}
\hline \multirow[b]{2}{*}{$\begin{array}{l}\text { No. } \\
\text { Urut }\end{array}$} & \multirow[b]{2}{*}{$\begin{array}{c}\text { Kelas } \\
\text { Interval }\end{array}$} & \multicolumn{5}{|c|}{ Frekuensi } \\
\hline & & $\begin{array}{c}\text { Batas } \\
\text { Bawah }\end{array}$ & $\begin{array}{l}\text { Batas } \\
\text { Atas }\end{array}$ & Absolut & Relatif & Kumulatif \\
\hline 1 & $60-65$ & 59.5 & 65.5 & 5 & 5.75 & 5.75 \\
\hline 2 & $66-71$ & 65.5 & 71.5 & 2 & 2.30 & 8.05 \\
\hline 3 & $72-77$ & 71.5 & 77.5 & 11 & 12.64 & 20.69 \\
\hline 4 & $78-83$ & 77.5 & 83.5 & 14 & 16.09 & 36.78 \\
\hline 5 & $84-89$ & 83.5 & 89.5 & 21 & 24.14 & 60.92 \\
\hline 6 & $90-95$ & 89.5 & 95.5 & 28 & 32.18 & 93.10 \\
\hline 7 & $96-101$ & 95.5 & 101.5 & 6 & 6.90 & 100.00 \\
\hline \multicolumn{4}{|c|}{ Total } & 87 & 100.00 & \\
\hline
\end{tabular}

Tabel 3 menunjukan bahwa 8,05\% dari responden merasa tidak setuju pada penerapan budaya perusahaan (nilai tersebut diperoleh dari persentase frekuensi relatif kelas interval pertama diakumulasikan dengan presentase frekuensi relatif kelas interval kedua), 28,73 \% dari responden merasa kurang setuju pada penerapan budaya perusahaan (nilai tersebut diperoleh dari persentase frekuensi relatif kelas ketiga diakumulasikan dengan presentase frekuensi relatif kelas interval ke-empat), 63,22\% dari responden merasa setuju pada penerapan budaya perusahaan (nilai tersebut diperoleh dari persentase frekuensi relatif kelas kelima diakumulasikan dengan presentase frekuensi relatif kelas keenam dan presentase frekuensi relatif kelas ketujuh).

Sebelum dilakukan uji hipotesis lebih lanjut, instrumen penelitian ini telah melalui uji validitas dan uji reliabilitas (cronbach alpha). Dari uji validitas diperoleh bahwa nilai $r$ (Corrected Item-Total Correlation) untuk semua butir pertanyaan memperoleh hasil $>0,3$ yang berarti seluruh butir pertanyaan tersebut valid sedangkan berdasarkan uji reliabilitas (cronbach alpha) diperoleh hasil 0,979 yang berarti instrumen penelitian lulus uji reliabilitas.

Dari instrumen yang dilakukan dengan skala lima diperoleh rentang teoritis antara 18 - 90. Rentang skor empiris diperoleh skor minimal 62 dan skor maksimal 89, dengan rentang skor sebesar 27. Nilai rata - rata 76,56. Median dengan nilai 78, modus dengan nilai 83, varians dengan hasil 41,412 dan standar deviasi sebesar 6,43. Berikut tabel distribusi frekuensi untuk kinerja user. 
Tabel 4 Tabel Distribusi Frekuensi Penerapan GCG (Y)

\begin{tabular}{|c|c|c|c|c|c|c|}
\hline \multirow{2}{*}{$\begin{array}{l}\text { No. } \\
\text { Urut }\end{array}$} & \multirow[b]{2}{*}{ Kelas Interval } & \multicolumn{5}{|c|}{ Frekuensi } \\
\hline & & $\begin{array}{c}\text { Batas } \\
\text { Bawah }\end{array}$ & $\begin{array}{c}\text { Batas } \\
\text { Atas }\end{array}$ & Absolut & Relatif & Kumulatif \\
\hline 1 & $62-65$ & 61.5 & 65.5 & 4 & 4.60 & 4.60 \\
\hline 2 & $66-69$ & 65.5 & 69.5 & 7 & 8.05 & 12.64 \\
\hline 3 & $70-73$ & 69.5 & 73.5 & 17 & 19.54 & 32.18 \\
\hline 4 & $74-77$ & 73.5 & 77.5 & 15 & 17.24 & 49.43 \\
\hline 5 & $78-81$ & 77.5 & 81.5 & 19 & 21.84 & 71.26 \\
\hline 6 & $82-85$ & 81.5 & 85.5 & 21 & 24.14 & 95.40 \\
\hline 7 & $86-89$ & 85.5 & 89.5 & 4 & 4.60 & 100.00 \\
\hline & Tot & & & 87 & 100.00 & \\
\hline
\end{tabular}

Tabel 4 menunjukan bahwa $12,11 \%$ dari responden merasa tidak setuju pada penerapan GCG (nilai tersebut diperoleh dari persentase frekuensi relatif kelas interval pertama diakumulasikan dengan presentase frekuensi relatif kelas interval), 36,7\% dari responden merasa kurang setuju pada penerapan GCG (nilai tersebut diperoleh dari persentase frekuensi relatif kelas k-tiga diakumulasikan dengan presentase frekuensi relatif kelas ke empat), dan 50,58\% dari responden merasa setuju pada penerapan GCG (nilai tersebut diperoleh dari persentase frekuensi relatif kelas ke lima diakumulasikan dengan presentase frekuensi relatif kelas ke enam dan ke tujuh).

Uji persyaratan analisis merupakan suatu syarat yang harus dipenuhi agar analisis regresi dapat dilakukan, baik untuk kepentingan prediksi maupun untuk pengujian hipotesis. Tiga syarat yang harus dipenuhi sebelum melakukan analisis regresi, baik regresi linier sederhana maupun regresi ganda, yaitu (1) uji normalitas dengan galat taksiran $(\mathrm{Y}-\hat{\mathrm{Y}})$ dari suatu regresi sederhana, (2) uji homogenitas varians kelompok kelompok skor Y yang dikelompokkan berdasarkan kesamaan data variabel predictor (X), dan (3) uji linieritas bentuk regresi $\mathrm{Y}$ atas $\mathrm{X}$ untuk regresi sederhana. Berdasarkan ketiga persyaratan tersebut terdapat dua persyaratan yang disajikan pengujiannya, yaitu pertama, uji persyaratan normalitas galat taksiran regresi $\mathrm{Y}$ atas $\mathrm{X}$ dengan asumsi bahwa distribusi populasi yang normal tercermin dari distribusi sampel yang normal juga. Pengujian itu dilakukan karena pengujian hipotesis mensyaratkan bahwa sampel berasal dari populasi yang berdistribusi normal.

Kedua, uji persyaratan homogenitas varians kelompok skor $\mathrm{Y}$ berdasarkan kesamaan data $\mathrm{X}$ sedang uji kelinearan bentuk regresi sederhana $\mathrm{Y}$ atas $\mathrm{X}$ akan diuji pada bagian pengujian hipotesis penelitian. Uji persyaratan homogenitas yang mengasumsikan bahwa skor variabel terikat $(\mathrm{Y})$ yang berpasangan dengan setiap skor variabel bebas $(\mathrm{X})$ memiliki varians yang homogen. Berdasarkan hasil pengujian normalitas diperoleh simpulan bahwa data berdistribusi normal dengan tingkat signifikan pada $1 \%$ sedangkan hasil pengujian homogenitas, diperoleh simpulan bahwa data bersifat homogen. 
Pengujian hipotesis bertujuan menjawab hipotesis secara empiris. Hipotesis yang dimaksud adalah asumsi atau simpulan sementara yang sudah dirumuskan pada Landasan Teori mengenai hipotesis penelitian, yaitu "Terdapat hubungan antara Budaya Perusahaan (X) dengan GCG (Y)”. Yang berarti hipotesis nol diterima.

Berdasarkan hasil perhitungan diperoleh hubungan antara Peranan Budaya Perusahaan dengan Penerapan GCG yang dinyatakan oleh persamaan regresi $\hat{\mathbf{Y}}=\mathbf{6 0 , 1}+$ 0,195X. Berdasarkan pada tabel pengujian signifikansi dan pengujian linearitas persamaan regresi tersebut, disimpulkan bahwa persamaan regresi $\hat{Y}=\mathbf{6 0 , 1}+\mathbf{0 , 1 9 5} X$ adalah siginifikan dan linear. Persamaan regresi tersebut memberi arti bahwa setiap peningkatan satu satuan skor budaya perusahaan akan diikuti kenaikan skor GCG sebesar 0,195 pada konstanta 60,1 .

Hasil perhitungan kekuatan hubungan antara budaya perusahaan (X) dengan GCG (Y) ditunjukkan koefisien korelasinya $=0,606$. Hal itu menunjukkan adanya hubungan yang kuat antara budaya perusahaan dengan GCG.

Tabel 5 Uji Signifikansi Koefisien Hubungan Antara Peranan Budaya Perusahaan (X) dengan Penerapan GCG (Y)

\begin{tabular}{|ll|}
\hline Model & $\hat{\mathbf{Y}}=\mathbf{6 0 , 1}+\mathbf{0 , 1 9 5} \mathbf{X}$ \\
\hline Keterangan & $\mathrm{Y}=$ Penerapan GCG \\
& $\mathrm{a}=$ Konstanta \\
& $\mathrm{b}=$ Koefisien Estimasi \\
& $\mathrm{X}=$ Peranan Budaya Perusahaan \\
\hline
\end{tabular}

\begin{tabular}{ccc}
\hline Variabel Bebas & Koefisien & Signifikansi (t Hitung) \\
\hline Peranan Budaya Perusahaan & 0,195 & $\begin{array}{c}7,02 \\
\text { (Signifikan pada tingkat } 1 \%)\end{array}$ \\
\hline $\mathrm{N}=87 ; \mathrm{r}^{2}=0,367$ & &
\end{tabular}

Dari hasil penghitungan uji signifikansi koefisien hubungan tersebut $t_{\text {hitung }}=$ $\mathbf{7 , 0 1 8 8}$ lebih besar dari $t_{\text {tabel }}=\mathbf{2 , 3 7 4}$. Dengan demikian, dapat disimpulkan bahwa koefisien hubungan antara budaya perusahaan (X) dengan GCG (Y) sebesar 0,606 adalah signifikan. Hal itu berarti terdapat hubungan antara budaya perusahaan (X) dengan GCG (Y). Hasil koefisien determinasinya $\mathrm{r}^{2}=\mathbf{0 , 3 6 7}$ atau $36,7 \%$. Hal itu berarti bahwa budaya perusahaan mempengaruhi GCG sebesar 36,7\%.

Penelitian ini telah dipersiapkan semaksimal mungkin dengan melakukan perencanaan terlebih dahulu. Setiap butir pernyataan dalam kuesioner telah melalui tahap uji validitas dan uji reliabilitas, namun masih terdapat kelemahan dalam kuesioner tersebut terutama pada situasi responden dalam mengisi kuesioner tersebut.

Penelitian ini menggunakan skala Likert yang terdiri lima pilihan pada setiap butir pernyataannya. Butir pernyataan itu memiliki keterbatasan dan kelemahan karena masih memberi kesempatan kepada responden dalam menilai pernyataan yang ada 
dengan tidak menggambarkan keadaan yang sebenarnya sebagaimana dialami oleh responden sendiri. Pengumpulan data dilakukan secara survei sehingga kualitas data di luar kendali peneliti, tergantung dari kondisi responden dan faktor situasional lain.

\section{PENUTUP}

Hal yang menjadi budaya di PT Aneka Tambang, Tbk., yaitu inovasi dan bertindak berisiko, perhatian secara terinci, orientasi hasil, orientasi individu, orientasi kelompok, agresivitas, dan stabilitas. Hal yang menjadi bagian terpenting dalam GCG di PT Aneka Tambang, Tbk., yaitu transparansi, akuntabilitas, tanggung jawab, kemandirian, dan keadilan.

Dari hasil analisis regresi linear sederhana dan hubungan sederhana, dapat disimpulkan bahwa terdapat hubungan yang kuat antara Peranan Budaya Perusahaan (X) dengan Penerapan GCG (Y) sehingga hipotesis korelasi (Ho) diterima, yaitu Terdapat Hubungan Peranan Budaya Perusahaan (X) dengan Penerapan GCG (Y). Angka hubungan antara Budaya Perusahaan (X) dengan GCG (Y) menghasilkan angka 0,606. Hal itu menunjukkan hubungan yang kuat antara Budaya Perusahaan (X) dengan Penerapan GCG (Y). Kekuatan tersebut didapat berdasarkan hasil pengujian signifikasi korelasi sebesar $\mathrm{t}$ - hitung $=0,70188>\mathrm{t}-$ tabel $=2,374$ adalah signifikan. Hal itu menunjukkan semakin baik Budaya Perusahaan (X), semakin baik GCG (Y).

Koefisien determinasi $\left(\mathrm{r}^{2}\right)$ sebesar 0,367 atau $36,7 \%$ yang merupakan pengkuadaratan dari $\mathrm{r}$ atau koefisien korelasi sebesar 0,606 . Dan $36,7 \%$ dari variasi yang terjadi dalam GCG (Y) dapat dijelaskan oleh variabel Budaya Perusahaan (X) melalui persamaan regresi $\hat{Y}=60,1+0,195 \mathrm{X}$ atau dapat diartikan bahwa Budaya Perusahaan (X) memberikan kontribusi sebesar 36,7\% terhadap GCG (Y) sementara 63,3\% (100\% $36,7 \%$ ) dipengaruhi oleh faktor lain. Pada uji signifikan (t hitung), menunjukkan angka 7,0188 > dari statistik tabel ( $\mathrm{t}$ tabel) sebesar 2,374 dengan tingkat signifikansi 0,01 (1\%). $\mathrm{Hal}$ itu berarti penerimaan terhadap $\mathrm{H}_{0}$ dan penolakan $\mathrm{H}_{1}$ atau koefisien regresi signifikan atau variabel Budaya Perusahaan (X) berpengaruh pada GCG (Y).

Manfaat pelaksanaan GCG bagi PT Aneka Tambang, Tbk., yaitu dapat meningkatkan shareholder value, mendapatkan dan menjaga kepercayaan investor dan kreditor, dapat menarik investor dari luar, memperoleh citra yang baik, dan menciptakan iklim yang sehat.

PT Aneka Tambang, Tbk. masih dapat meningkatkan penerapan budaya perusahaan guna lebih meningkatkan GCG dengan mempelajari pengaruh lain terhadap pelaksanaan GCG yang sebesar 63,3\%. PT Aneka Tambang, Tbk. perlu menginternalisasikan budaya yang ada, seperti orientasi individu dan orientasi kelompok serta mempertahankan orientsi hasil agar pelaksanaan GCG dapat tetap dipertahankan. Implementasi penelitian ini untuk perusahaan lain ada kemungkinan terjadi perbedaan. 


\section{DAFTAR PUSTAKA}

Aldridge, J.E. 2005. Good Corporate Governance: Tata Kelola yang Sehat. Edisi 1. Alih bahasa Sutojo, S. Jakarta: Penerbit Damar Mulia Pustaka.

Arasy, A. 2002. "Pengaruh Budaya Pimpinan, Budaya Individu, dan Budaya Organisasi terhadap Kreativitas Kerja Karyawan,” Jurnal Ekonomi, Vol.2 No.3, 127-158.

Gea, A.A. 2005. Character Building IV Relasi dengan Dunia: Alam, Iptek, dan Kerja. Jakarta: PT Alex Media Komputindo.

Lowney, C. 2005. Heroic Leadership: Praktik Terbaik Sebuah Perusahaan Berumur 450 Tahun yang Mengubah Dunia. Alih bahasa Rusli, R.A. Jakarta: Penerbit Gramedia.

Moeljono, D. 2005. Good Corporate Culture Sebagai Inti dari Good Corporate Governance. Jakarta: Penerbit Elex Komputindo.

Moorhead, G. and W.G. Ricky. 1999. Human Resources Management. $7^{\text {th }}$ Ed. New York: Prentice Hall, Inc.

Nawawi, H. 2003. Kepemimpinan Mengefektifkan Organisasi. Yogyakarta: Gajah Mada Press.

Triguno. 2000. Budaya Kerja. Jakarta: Penerbit Golden Trayon Press.

YPPMI. 2002. The Essence of Good Corporate Governance: Konsep dan Implementasi Perusahaan Publik dan Korporasi. Jakarta: Penerbit Yayasan Pendidikan Pasar Modal Indonesia. 